Wm. M. Wheeler, on "The Polymorphism of Social Insects."

On Saturday, December 29, a general meeting and luncheon was given at the College of the City of New York, where lectures were given on "The Effort to Save Niagara," by Dr. John M. Clarke, and " On the Industries of Niagara," by Prof. C. F. Chandler. In the afternoon a general meeting was held at the American Museum of Natural History to attend the ceremonies connected with the unveiling of the busts of American men of science presented to the museum by Mr. Morris K. Jesup. Fiveminute speeches of presentation were made by Dr. H. C. Bumpus, Hon. Joseph H. Choate, Dr. S. Weir Mitchell, the representative of the German Ambassador, Dr. C. Hart Merriam, Dr. N. L. Britton, Dr. R. S. Woodward, Dr. Arthur T. Hadley, Dr. Hugh M. Smith, Dr. W. K. Brooks, and Dr. H. F. Osborn. A reception was given at the museum in the evening by the trustees of the museum and the New York Academy of Sciences, with an exhibition of scientific progress by the academy, including a demonstration and short addresses.

The most important actions taken by council and by the association at the New York meeting were as follows:-(1) The addition of a new section to the association, viz. L-Education; (2) the change of the title of Section H from "Anthropology" to "Anthropology and Psychology"; (3) a standing committee of fifteen on seismology was appointed; (4) a Darwin memorial committee of ten was appointed to consider the manner in which the association may suitably commemorate the fiftieth anniversary of the publication of the first edition of "The Origin of Species," and this committee was authorised to make overtures to the British Association in order to ascertain whether joint action in this matter cannot be taken; (5) the permanent secretary was authorised to publish hereafter in the official programme of the association all the programmes of all the affiliated societies, whether holding joint sessions with the sections of the association or not; (6) Section E and other sections desiring to do so were authorised to hold a summer meeting during the summer of $1907 ;(\tau)$ a memorial was presented to Congress urging the passage at the present session of the Bill creating forest reserves in the White Mountain region and in the Lower Appalachian region.

In accordance with the policy adopted of recent years, the general committee chose as the place of next meeting the city recommended by the last general committee, namely, Chicago, and recommended to the next general committee that the meeting of $1908-9$ should be held in Baltimore. A cordial invitation was received from the president of the University of Chicago, from the Field Columbian Museum and from the Mayor of the city, and also from the president of Johns Hopkins University, of Baltimore. The alternation of eastern and mid-western meetings appears to be, on the whole, satisfactory, although the eastern meetings have been much more largely attended. Chicago, however, is a great scientific centre, and is so easily accessible by rail that the next meeting bids fair to be a large one.

The officers elected for the Chicago meeting were as follows :-President, Prof. E. L. Nichols, Cornell University, Ithaca, N.Y.; vice-president and chairman of Section A (Mathematics and Astronomy), Prof. E. O. Lovett, Princeton University, Princeton, N.J.; vice-president and chairman of Section B (Physics), Prof. Dayton C. Miller, Case School of Applied Science, Cleveland, Ohio; vicepresident and chairman of Section C (Chemistry), Prof. H. P. Talbot, Massachusetts Institute of Technology, Boston, Mass.; vice-president and chairman of Section D (Mechanical Science and Engineering), Prof. Olin H. Landreth, Union College, Schenectady, N.Y.; vice-president and chairman of Section E (Geology and Geography), Prof. J. P. Iddings, University of Chicago, Chicago, Ill.; vice-president and chairman of Section F (Zoology), Prof. E. B. Wilson, Columbia University, New York, N.Y.; vice-president and chairman of Section G (Botany), Prof. C. E. Bessey, University of Nebraska, Lincoln, Neb. vice-president and chairman of Section $\mathrm{H}$ (Anthropology), Dr. Franz Boas, American Museum of Natural History, Central Park, New York, N.Y.; vice-president and chair- man of Section I (Social and Economic Science), Dr. John Franklin Crowell, cio The Wall Street Gazette, New York, N.Y.; vice-president and chairman of Section K (Physiology and Experimental Medicine), Dr. Ludwig Hektoen, University of Chicago, Chicago, Ill.; vice-president and chairman of Section L' (Education), Hon. Elmer Brown, U.S. Commissioner of Education, Washington, D.C.

\section{SOME RECENT WORK OF GEOLOGICAL SURVEYS}

THE Summary of Progress of the Geological Survey of the United Kingdom for 1905 (London: H.M. Stationery Office, 1906, price Is.) contains new information regarding the granites of Cornwall and the results of subterranean vapour-action on their flanks. The associated elvan-dykes are now recognised as cutting the granite, and not as offshoots from the more coarsely crystalline mass. The Ordovician beds of South Wales are being divided into zones, under the care of Mr. Strahan. We may note that the spelling "Llandilo" is officially accepted. At the same time, the Coal-measures of South Wales continue to receive close attention; and Messrs. Gibson and Cantrill describe the progress of the search for coal beneath the Permian and Trias of the English Midlands. Mr. Flett's account of the Lewisian rocks that have been recognised within the area of the Moine gneisses in northern Scotland shows that the ancient intrusive gneisses are accompanied by still older rocks of sedimentary origin, which have been metamorphosed by them. Following Dr. Peach, the occurrence of an unconformity between this older complex series and the Moine gneisses is regarded as extremely probable (pp. 103, 166, \&c.). $\mathrm{Mr}$. Howe furnishes a summary of the work done in the museum at Jermyn Street on the samples of road-metal tested in Mr. Lovegrove's machines at Hornsey. The full results are now available in a separate work (see Nature, vol. lxxv., p. 220).

The Geological Survey also issued in 1906 a colourprinted edition of Sheet $\mathrm{r}$ ro of the English map, with the superficial deposits represented, and an accompanying memoir of 138 pages on "The Geology of the Country around Macclesfield, Congleton, Crewe, and Middlewich" (price $2 s .6 d$.). The only things that we miss in this memoir are photographic illustrations to show the contrast between the drift-covered plain of Cheshire and the scarped and broken country leading northwards from Mow Cop. Even a vignette of Moreton Hall, and another of the spoil-heaps of a coal-mine, might express the social and industrial contrast, which is so well known to roadtravellers between Chester and the Pennine Chain. The "general description," however, makes good amends from the point of view of structural geology. The details of the superficial deposits are the newest feature in the memoir, and the glacial beds are regarded as the product of an ice-sheet about Iroo feet in thickness (p. 79). The marine shells found in the high-level gravels " may well have been caught up by the ice in its passage over the Irish Sea." Examples of these occur east of Macclesfield at a height of 1200 feet above the sea. But Mr. T. I. Pocock, who treats of this area in the memoir, believes that the shelly sands formerly to be seen under Macclesfield itself (p. 84), at a height of about 450 feet, may have been deposited in a shallow sea. The perfect state of preservation of large numbers of the molluscan remains, and the absence of glacial indications in the beds, influence him in this opinion, which is quite in accordance with what is admitted in countries outside the British Isles. At home, however, it is certain to be questioned, as is also the dim suggestion of an inter-Glacial epoch in the succession of events tabulated upon p. 88 . The economic geology of the area is dealt with in chapter ix.

Earlier in the year, Mr. G. Barrow's memoir on "The Geology of the Isles of Scilly" (price rs.) was issued, to accompany a convenient map which includes the whole group in a single sheet. Here photography has freely been called in, and the relations of the isles to human interests are well touched on. Mr. Flett's petrographic notes appear, 
happily, in connection with the description of the rockmasses in the field. An outlier of gravel (p. 15), "largely composed of Chalk-flints and Greensand-chert," forms a cap on the eastern promontory of St. Martin's, and may be a relic of a river-gravel, spread from Dartmoor over a continuous land-surface in Eocene times. The old preGlacial beach, now near sea-level, has been raised at least 40 feet, and again lowered by that amount, since its formation (p. 33); the evidence of this comes from the mainland, but is sufficiently conclusive. The warping in the beach itself may be brought to the attention of those who are captivated by the theory of fluctuations in the volume of the sea rather than by that of recent movements of the land.

Part iv. of the Administration Reports of Ceylon for 1905 includes one on the Mineralogical Survey, by the director, Dr. A. K. Coomaraswamy. This raises a number of points of great interest to the petrographer as well as the mineralogist. The graphite of Ceylon is regarded as a product of vein-filling processes, following the reasoning of Weinschenk-here styled, as so often happens, Weinschenck. If, however (p. E $E_{3}$ ), the crystalline limestones of the district are organic, the graphite may possibly have had "an indirect organic origin." The similarity of the deposits in Ceylon to those of Quebec, which are directly associated with limestone, is not so great as Osann has recently suggested. The discovery of thorianite by the director has led to investigations in a number of valleys (p. E 6) ; but, knowing the country intimately, Dr. Coomaraswamy does not believe that it would be practicable to divert the courses of the streams to facilitate the raising of the material. An illustrated account is given of the native method of dredging for gems, and there is a fine plate showing the weathered surface of limestone associated with bands and lumps of granulite. A parallel to this "interstreaking" of the two rocks can surely be found in the west of our own islands, where the "granulite" is clearly an invader in the limestone. This report, so closely and simply written, provides more agreeable reading than many ambitious volumes with wide margins and encyclopædic information.

From the New Zealand Geological Survey we have received Bulletin No, I, describing the geology of the Hokitika sheet, by J. M. Bell and Colin Fraser (pp. xii + 102, 1906). Some of the topographical work has to be carried out by the Geological Survey, and maps are usefully added in an envelope at the end of the bulletin. The area described lies in North Westland, and contains both alluvial gold and coal. The relics of formerly extensive glaciers, with snowy gathering-grounds at a height of about 5500 feet above the sea, afford especially interesting features in a latitude of $43^{\circ} \mathrm{S}$. One of these narrow shrunken glaciers is shown in the illustration here selected (Fig, I), and the memoir abounds in photographic views which will appeal equally to the geographer and the geologist. It should have been noted, perhaps, by the authors that some of these views represent more than the perpetual snow. On p. 21 it is suggested that the glaciation began to spread from the new mountain-range "during or perhaps just following Lower Cretaceous times." On the next page this is, we think, corrected by the statement that "glaciation started in Miocene time." The great advance of the ice, reducing the island to the condition of Greenland, probably took place in the early Pleistocene. Whether this was due entirely to the upheaval of a mountain-chain across the direction of the prevalent winds is left an open question. We gather that the great mountain-building movements were of early Eocene age.

NO. I 943 , VOL. 75$]$
The authors have no doubt as to the excavating power of the glaciers in the past, and quote the forms of the lake-bottoms in support of their conclusions. The petrology is illustrated by a striking series of enlargements from rock-slices, reminding one, on a still bolder scale, of the pioneer work of the late $\operatorname{Sir} R$. Daintree. Nephrite (p. 69) is found occurring as segregations in talc-rock or talc-serpentine-rock, the lumps being from about I inch to 2 feet across; these are pointed out (p. 99) as of economic value. On p. 93 we have the interesting suggestion that boulders of "grauwacke" in Butcher's Creek supply sufficient ferrous carbonate to act, when they decompose, as precipitants of gold in the solutions permeating the surrounding gravels. These boulders were examined chemically, owing to the greater richness of the gravel round them as compared with that round boulders of other rocks. Another remarkable record is the discovery of platinum in quartz-veins (p. 96). The whole bulletin, with its introduction on the botany, soil, climate, and communications of the area, shows that the survey has a high conception of its duties in carrying on the scientific investigation of New Zealand.

The Annual Report of the State Geologist of New Jersey for 1905 shows the local survey in cooperation with that of the United States, and even competing with it in the

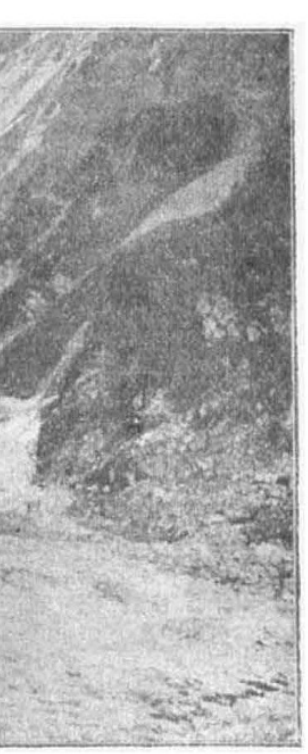

Grave Creek Glacier, with Mount Walter (6350 feet) at the back.

production of geological maps on a large scale (p. 4). As is now the case with most surveys, economic observations occupy an important place, and it is doubtless found that the necessity for close scrutiny and all-round questioning which such inquiries involve reacts favourably on the character of the more purely scientific work. In New Jersey, however, the Geological Survey goes outside ordinary lines, and deals, for instance, with water-supply and coast-protection from an engineering point of view. Mr. Berry describes (p. 135) the Cenomanian flora of the Magothy beds at Cliffwood. Messrs. Parmelee and McCourt contribute ninety pages on the nature and uses of peat, and on the peat-deposits of the State, with a general bibliography.

The recent work of the United States Geological Survey has been dealt with lately in a special article (NATURE, December 20, 1906, p. 182). Mr. Calhoun has now issued a professional paper on "The Montana Lobe of the Keewatin Ice-sheet," which contains interesting details (p. 4o, \&c.) as to the influence of the main ice-sheet on the course of the Missouri River. Students of dry rivercourses in glaciated areas will find the Shonkin Sag of interest, a channel with characteristically fresh surface- 
features (Fig. 2), and cut to a depth of 600 feet across, and not down, the slope of a hillside for a length of eighty miles (pp. 12 and 43). This is explained by the action of an cverflow-stream from a lake held in between the icefront and the hills. Parts of several pre-Glacial streamcuts were utilised in its course.

The work of the Geologische Reichsanstalt of Vienna may conveniently be touched on in this article. In vol. Ivi. of the Jahrbuch of this institute (May, r9o6, p. 298) Dr. Stuchlik attributes a lateritic origin to the "bunte Mollasse " of the Oligocene of southern Bavaria, and urges that the red ferruginous material was washed down from tropical deltas into a shallow sea. B. Granigg's paper (p. 367 ) on the Ober-Mölltal in Carinthia contains some observations on the origin of serpentine; and it is instructive to note that the intrusive masses from which this rock has been produced have metamorphosed the adjacent mica-schist and quartzite in very various degrees. Contactalteration is at times hardly perceptible, a fact that may be taken into account in the discussion on the origin of the South African diamantiferous material. In the Verhandlungen of the Reichsanstalt, 1906, pp. 146-164, Dr. F. E. Suess gives a general account of the geology of the complicated district in the environs of Brünn. The

Thus in many cases they were deposited in gulfs running along the hollows of an ancient crystalline series. The author strips away these sediments, and seeks to trace the surface of a central Alpine land-mass denuded in prePalæozoic times. G. A. J. C.

\section{OCEANOGRAPHICAL RESEARCH.}

THE Prince of Monaco presided at the formal opening of the Scottish Oceanographical Laboratory at Edinburgh on the afternoon of Wednesday, January 16. A distinguished gathering of representative naturalists from the leading cities of Scotland took part in the ceremony. On the motion of the Lord Provost of Edinburgh, the Prince of Monaco was called upon to take the chair. A brief explanatory statement of the genesis and development of the laboratory and of the end aimed at was given by Mr. W. S. Bruce, the leader of the Scottish Antarctic Expedition and the founder and director of the laboratory. He showed how Scotland might be regarded as the cradle of oceanography, Edinburgh having been associated with the study of the oceans for a longer period than any other place in the world. The gathering together and arrangement of the material had been going on for years, and represented the work of eight scientific expeditions. In many respects it was an absolutely unique collection. The place it was now in was essentially a workshop for oceanography, and Mr. Bruce appealed to the people of Scotland to support this movement to place oceanographical research on a permanent footing. There were men able and willing to do the work if once the laboratory were properly established and affiliated to the great teaching institutions of the country.

In a short address the Prince of Monaco paid a high tribute to the admirable work which had been accomplished by $\mathrm{Mr}$. Bruce and his companions in the Antarctic seas. Their expedition had been probably the most fruitful of all the expeditions carried out about the same time, and yet by far the most economical. Seven other speakers, representing various interests, spoke as to the claims Mr. Bruce's new venture had on the people of Scot-

FIG. 2. The wall of the Shonkin Sag, a valley of glacial drainage in Montana.

sheet of the geological map described includes part of the ancient Bohemian plateau on the north-west, and part of the Cainozoic foothills of the Carpathians on the southeast. The picturesque and varied scenery on the old highway from Hungary to Prague is recalled to us in this lucid memoir. Brünn, little visited as it is, should clearly be an exceptional centre for the study of geology. The Ortler group furnishes W. Hammer (p. 174) with material for a discussion of Termier's views on Alpine structure. Dr. Kossmat (Jahrbuch der k.k. Reichsanstalt, 1906, p. 274) similarly finds himself involved with Termier and Lugeon in the "Gebiet zwischen dem Karst und dem Zuge der Julischen Alpen." A specialised congress on Alpine structure, with months of field-excursions, would be needed for the answering of all these questions; but even then the new views daily propounded would effectually overwhelm the answers. M. Vacek (Verhandlungen, 1906, p. 203) is allowed free scope for a highly controversial paper on the basin of Graz, in which he compares the "green beginner" in geology, who rushes into tectonics, to a stutterer delivering a public speech. The name of the specially "green" one is presently shouted across the barriers of this scarcely edifying tourney. The geological sections given are, of course, of considerable interest, and show a country rich in transgressions and unconformities. Vacek points out the need for considering the isolated masses of Palæozoic and Mesozoic sediments in relation to the geography of the times when they were laid down. land. Sir William Turner referred to the close connection which the University of Edinburgh had had with the Challenger expedition and with later expeditions of a like character. Dr. Dobbie said that the seals and birds which the Scottish Antarctic Expedition had presented to the Royal Scottish Museum were probably unsurpassed by any like collection in any museum of the kingdom, and that other museums had greatly benefited through the generosity of Mr. Bruce. Dr. Horne, as representing various scientific societies, made special reference to the geographical knowledge which had been gained by the staff of the Scotia, to the practical sympathy which the Scottish Geographical Society had taken in the expedition, and to the generous manner in which the Royal Society of Edinburgh, in spite of its straitened means, had undertaken the publication of the memoirs describing the results. Prof. Arthur Thomson, as representing other Scottish universities, directed particular attention to the character of the Oceanographical Laboratory as a place where a man could train himself for oceanographical work. Mr. Henry Coates, of the Perthshire Society of Natural Science, commented on the value of the collections in the laboratory being arranged as a regional museum. Dr. Rottenburg, of Glasgow, and Mr. Robert M'Vitie, of Edinburgh, expressed their sympathy with a project which seemed to be a natural consequence of the Antarctic Expedition, the success of which had rejoiced the hearts of the many who had been interested in it. 